\title{
The Impact of E-mind Mapping Strategy on the Academic Achievement of Jordanian 9th Grade Students in Citizenship and Civic Education Course
}

\author{
Dr. Ali Suleiman Al-Swalha ${ }^{1}$ \\ ${ }^{1}$ Educational Technology, Al-Balqa Applied University, Al-huson University College, Jordan \\ Correspondence: Dr. Ali Suleiman Al-Swalha, Associate Professor in Educational Technology, Al-Balqa Applied \\ University, Al-huson University College, P. O. Box 21510, Irbid, Jordan.
}

Received: December 18, 2020

Accepted: January28, 2021

Online Published: January 29, 2021

doi:10.5430/ijhe.v10n3p223

URL: https://doi.org/10.5430/ijhe.v10n3p223

\begin{abstract}
The present study aimed at identifying the impact of the e-mind mapping strategy on the academic achievement of Jordanian 9th grade students in the citizenship and civic education course. It was carried out during the second semester of the academic year 2019/2018 through adopting a quasi-experimental approach. It was carried out in Princess Sukayna bent Al-Hussain School for girls in Amman, Jordan. The sample consists from (55) female students who were chosen through the purposive sampling technique. Those students were divided into control and experimental groups. Pre-test and post-tests for measuring achievement were used. Based on the process of analyzing data, the e-mind mapping strategy can effectively improve the achievement of Jordanian $9^{\text {th }}$ grade students in the citizenship and civic education course. The researcher recommends providing Jordanian citizenship and civic education teachers with special training programs about the technology-based instructional strategies. Such training programs must shed a light on e-mind mapping strategy
\end{abstract}

Keywords: academic achievement, Jordan, e-mind mapping strategy, mind mapping strategy, citizenship and civic education course

\section{Introduction}

Teachers -including the teachers of the citizenship and civic education course- employs various teaching strategies. Such strategies include "mind mapping strategy". The mind mapping strategy refers to employing a graphic organizer where main categories radiate from a central idea. Subcategories are derived from the main categories. It is a visual strategy that is employed for generating ideas, taking notes, organizing thinking, and developing concepts (Al-Jarf, 2011, p. 4). It was developed by Tony Buzan during the 1970s (Abdulbaset, 2016). It serves as an graphic organizer, and a schema for presenting, organizing, generating, and classifying ideas, words, concepts and tasks (Abdulbaset, 2016). It contributes to improving students' motivation to learn, and raise their achievement and expand their knowledge (Jones et al., 2012)

Due to the significance of employing technology in classroom on students' achievement and motivation, teachers have been increasingly using technology in classroom. They have been increasingly using technology-based instructional teaching strategies (Harris et al., 2016). Thus, many teachers use the e-mind mapping strategy. The e-mind mapping strategy refers to the use of electronic graphic organizers that are created and presented through computers for presenting, organizing, generating, and classifying ideas, words, concepts and tasks (Abdulbaset, 2016).

The e-mind mapping strategy contributes to raising students' academic achievement (Al-Shdaifat et al., 2019). It allows users to draw, fix, and save graphic organizers through using a computer program. The e-mind map can be converted into a PDF or a picture (Al-Mutairi, 2016). It allows students to arrange ideas, learn and recall specific information (Buzan \& Buzan, 1996). It contributes to improving reading, problem solving, and decision-making (Buzan, 2006).

The e-mind mapping strategy contributes to improving students' cognitive skills and ability to perform cognitive processes. It improves students' long term retention of information. It promotes deeper understanding for factual knowledge. It let students organize the information stored in their memories in an efficient manner (Farrand et al., 
2002). It allows students to take notes efficiently and organize them well. It allows students to identify the link between various pieces of information (Tucker et al., 2010). It provides students with sensory experiences, because the e-mind maps may include videos, images, audio files, visual effects and etc. (Avgerinou and Ericson, 1997).

It should be noted that the Jordanian Ministry of Education has been providing much attention to the citizenship and civic education course in schools. That is because the latter course is very significant. For instance, the latter course contributes to providing students with adequate knowledge about their homeland. It contributes to promoting citizenship values, loyalty and belonging among students (Subheyyin et. al., 2017). It contributes to providing students with knowledge about their origin, and antecedents. It contributes to developing positive attitudes among students towards their homeland and their cultural heritage. It contributes to raising up citizens who love their homeland and seek defending it (The Jordanian Ministry of Education, 1997; Alazzi, 2012).

The citizenship and civic education course enables students to identify their civil rights and duties (The Jordanian Ministry of Education, 1997; Alazzi, 2012). It contributes to promoting good economic, social and political values among students. It contributes to promoting compliance with customs, values and traditions and respect for them. It contributes to promoting democracy, justice and equality in society and compliance with laws. It contributes to promoting respect for the governor and public figures who made sacrifice for meeting public interests. It encourages students to make sacrifices for the benefit of their homeland. It encourages students to express their views respectfully without having fear. It contributes to promoting negative values for radicalism and extremism and showing humbleness (Al-Khazaleh, 2018).

The citizenship and civic education course encourages and motivates students to engage in voluntarily works that serve their society. In other words, it encourages students to think in serving their homeland regardless of the financial gain. It encourages students to engage in religious and showing honesty and integrity. Thus, it plays a significant role in promoting solidarity and improving the social relationships between the members of the society (Al-Khazaleh, 2018).

It should be noted that delivering citizenship education effectively shall promote good economic, social and political values (Al-Khazaleh, 2018). Delivering citizenship education effectively shall encourage students to engage in activities in school, home, and community for meeting national interests. It shall promote democracy and encourage on to engage in political activities. It shall encourage students to help the poor and do his duties (e.g., paying taxes). It shall promote compliance with the law. It shall promote awareness about the significance of justice, and equality (Geboers et al., 2013). It shall contribute to fighting against violent, extremist, and terrorist acts which have been increasing (Haynes and Passy, 2013). In simple words, it shall contribute to the development and advancement of individual and society.

Due to the role of citizenship education in fighting against violent, extremist, and terrorist acts which have been increasing, school managements, and educators must search for effective teaching strategies to deliver citizenship education effectively. They can search for such strategies through conducting studies to explore the effectiveness of teaching strategies in this regard. Therefore, the problem of this study is represented in the following question (How effective is the e-mind mapping strategy in raising the academic achievement of Jordanian $9^{\text {th }}$ grade students in the citizenship and civic education course)?

\section{Hypothesis}

The following hypothesis was developed by the researcher:

H0: There isn't any statistically significant difference - at the statistical significance level of $\alpha \leq 0.05$ - between the control and experimental group in terms of achievement on the post-test in the citizenship and civic education course.

\section{Question}

The present study aimed to answer the following question

Q 1. Is there any statistically significant difference - at the statistical significance level of $\alpha \leq 0.05$ - between the control and experimental group in terms of achievement on the post-test in the citizenship and civic education course?

\section{The Study's Limits}

The present study was conducted during the second semester of the academic year (2019/2018) in Princess Sukayna bent Al-Hussain School for girls. The latter school is a Jordanian public school located in Amman, Jordan. 


\section{The Study's Significance}

The present study is significant due to the reasons listed below:

a- The results of this study contribute to finding an effective strategy for promoting citizenship values among students and making them loyal to their homeland. Employing an effective strategy in the citizenship and civic education course shall contribute to fighting against terrorism and extremism. It shall contribute to promoting democracy in the Jordanian society and respect for the Jordanian government

b- This study is the first study in Jordan that investigates the effectiveness of employing the e-mind mapping strategy in raising students' level of academic achievement in the citizenship and civic education course. Thus, it fills a gap in the relevant literature.

c- This study serves as a significant reference for any researcher who wants to investigate the effectiveness of employing the e-mind mapping strategy in raising students' level of academic achievement in any course.

d- This results of this study enable the decision makers in the Jordanian Ministry of Education to make sound decisions that improve the quality of citizenship and civic education. They enable those decision makers to develop plans for fighting against terrorism and extremism.

\section{Theoretical Literature}

\subsection{Mind Maps}

According to Buzan and Buzan (1993), mind maps are graphic organizers that can unleash one's cognitive and mental potentials. They enable one to think in a radiant manner and contribute to enhancing one's cognitive functions and higher thinking skills (Buzan and Buzan, 1993). Al-Refa'ie (2006) suggests that the mind mapping strategy enables students to think creatively, solve problems, feel comfortable in classroom, and think positively. This strategy improves one's ability to think efficiently. It also enables students to identify the relationships and links between different variables, and retrieve information efficiently. It allows one to summarize the most important ideas in the lesson without relying on others to do that. It enables students to prepare and study for the exams efficiently. Furthermore, it facilitates the processes of searching for information and presenting it. That is because the mind map presents information in an organized manner (Al-Refa'ie, 2006)

Al-Haroun (2007) believes that the mind mapping strategy increases students' self-confidence when presenting information before their class mates. That is because the mind map allows the student to present his information and express his ideas in an organized manner. The mind mapping strategy also makes complex information look easier. It facilitates the process of understanding complex information. It enables students to enjoy learning and allows them to show creativity. For instance, students have the opportunities to change the items on the mind maps. They may be asked to come up with original ideas to be placed on the map. The mind mapping strategy improves students' thinking skills and ability to retrieve information (Al-Haroun, 2007)

According to Hilal (2007), the mind mapping strategy allows students to organize their ideas, retrieve information easily and learn quickly. It allows students to think freely and holistically. It promotes a deeper understanding for the academic material. It contributes to solving problems in a creative manner and utilize information efficiently. It contributes to improving students' cognitive skills, and retention. It turns students into active learners and encourages them to engage actively in the lesson activities (Hilal, 2007).

According to Al-Jarf (2011), the mind mapping strategy is a visual teaching strategy for taking notes, generating ideas, organizing thoughts and enhancing the learning process. He believes that it can guide learners in the learning process. It also enables students to build connections between concepts and variables. This is done when the categories of a graphic organizer radiate from a central idea (p. 4).

\subsection{E-mind Mapping Strategy}

Margulies (2001) suggests that the e-mind mapping strategy allows teachers to communicate effectively with their students. This strategy allows students to save their ideas and notes. It turns the learning process into an entertaining and enjoyable process. It allows students to use multimedia (e.g. photos and effects). It develops students' visual thinking skills. It should be noted that this strategy facilitates the processes of saving information and retrieving it. That's because one's visual memory is stronger than his auditory memory. Therefore, using photos and concepts jointly shall contribute to improving the learning outcomes, comprehension, academic performance and retrieval of information. That latter researcher believes that the e-mind mapping strategy is a very effective strategy for teaching all subjects (Margulies, 2001). 
Jonassen (2005) believes that the e-mind mapping strategy develops students' logical thinking and problem solving. Waqad (2009) states that this strategy allows students to summarize the ideas of the lesson and the whole curriculum. According to Zhang et al. (2010), the e-mind mapping strategy presents clearly the relationships that exist between keywords. It builds memory links between key words, pictures and color. It requires using the left and right hemisphere of the brain, and serves as an effective memory aiding tool (Zhang et al., 2010).

According to Hasan (2013), the e-mind mapping strategy enables students to organize information and develops advanced information models. It facilitates the process of memorizing information, as well as enables students to attach files and add lists and links. It enables students to update the recorded information and convert it into power point slides or into any other form to be presented before colleagues. It also allows students to cooperate with each other because several students can engage in designing the e-mind maps. It allows students to re-arrange some icons in the e-mind map. It allows students to come up with new ideas and manage and organize data. It raises students' concentration level and improves the performance of their memories. It allows students to make sound decisions and connect the previous knowledge with the new information. Furthermore, it allows students to learn fast and gain much knowledge. It allows them to think freely without restrictions. It promotes a sense of creativity, and motivates students to learn. It encourages students to cooperate, and use photos, videos and links. Furthermore, students can exchange such maps and re-organize the icons such maps (Hasan, 2013).

Al-Balawi (2015) adds that teachers shall be able to take the individual differences between students into consideration when employing the e-mind mapping strategy. In addition, it enables students to organize ideas and information in their minds, and develop their skills. Due to employing this strategy, students shall become capable of developing new and original ideas and think holistically. Students shall simplify the complex information (Al-Balawi, 2015).

Abdulbaset (2016) adds that e-mind maps consists from several elements (e.g. lines, arrows, geometrical shapes, pictures, colors and symbols). He points out that using various colors in e-mind maps can stimulate memory and promote creativity. He adds that the lines in such maps can connect ideas with each other. As for the arrows, they are used to identify the flow of ideas (Abdulbaset, 2016).

Abdulbaset (2016) adds that the e-mind mapping strategy enables students to analyze information efficiently, express their ideas and think critically. This strategy enable students to explain concepts, theories, principles, values, skills and ideas. It allows the students attending conferences to take notes and record steps and instructions. It is an effective tool for brainstorming ideas, and encouraging students to come up with examples and ideas (Abdulbaset, 2016).

According to Abdulbaset, (2016), this strategy allows students to figure out the relationships between concepts and ideas. It allows students to organize a great amount of information. It allows students to arrange priorities and review information fast. It can be used for getting prepared for an interview or oral or written tests. It allows students to make plans for studying various subjects. It allows students to plan ideas before writing a book or an article (Abdulbaset, 2016)

According to Abdulrazeq (2016), the e-mind mapping strategy makes learning fun, and make studying easier. It also improves the memory performance. It also allows learners to generate ideas, and connect complicated ideas with each other. It enhances the cognitive functions of the brain. It can be used by teachers to identify the things that students didn't understand. It motivates students to learn and lets them think in a radiant manner. Through thinking in a radiant manner, students shall be capable of generating numerous original ideas.

\section{Empirical Literature}

Through adopting a quasi-experimental approach, Al-Fawri (2009) investigated the impact of using the mind mapping strategy on students' achievement in the social studies course in Oman. 60 ninth grade students were sampled. They were chosen from Zainab Al-Thaqfeye School. They were grouped into experimental and control groups. Data got collected through using a survey, pre-test and post-test. The researcher found that there are significant differences exist between both groups in terms of scores on the post-test. This difference is for the favor of the experimental group in the social studies course. The researcher concluded that students have positive attitudes towards the use of the mind mapping strategy in this course.

Jbeili (2013) investigated the impact of using digital mind maps and conventional mind maps on achievement in science course. He sampled 44 sixth grade female students in Saudi Arabia. Those students were grouped into an experimental and a control group. Data got collected through using a survey, pre-test and post-test. E-mind maps were employed to teach the experimental group. The control group was taught through using the conventional mind 
maps. Based on data analysis, e-mind maps are more effective than conventional mind maps for improving students' achievement in the science course.

Bani Fares (2013) investigated the impact of mind maps on the acquisition of historical concepts and development of creative thinking skills. 60 students from a secondary school in Saudi Arabia were sampled. They were grouped into experimental and a control group. Data got collected through using a survey, pre-test and post-test. Based on the data analysis process, there's a statistically significant difference between both groups in terms of scores on post-test for the favor of the experimental group. Thus, mind maps contribute to acquiring historical concepts and developing creative thinking skills.

Al-Balawi (2015) investigated the impact of the conventional mind maps, concept maps, and e-mind maps on the development of students' creative thinking skills in social and national studies. 75 third grade secondary school students in Saudi Arabia were sampled. They were grouped into experimental and a control group. Data got collected through using a survey, pre-test and post-test. The researcher concluded that concept maps and e-mind maps are more effective than congenital mind maps for the development of students' creative thinking skills in social and national studies.

Al-Sherbini (2016) investigated the impact of using mind maps on the contemplative thinking skills in the social studies course in a secondary school in Egypt. He adopted an experimental approach. The sample was grouped into experimental and a control group. Data got collected through using a survey, pre-test and post-test. The researcher found that using mind maps is effective for developing students' contemplative thinking skills in this course.

Zaytoon and Baker (2016) investigated the effectiveness of using e-mind maps in improving the problem solving skills of $10^{\text {th }}$ grade Jordanian students in physics. The quasi-experimental approach was adopted. The experimental group was taught employing the e-mind mapping strategy and the control group was taught using the traditional teaching method. The sample was grouped into experimental and a control group. Data got collected through using a survey, pre-test and post-test. The researcher found that e-mind maps are more effective than conventional mind maps for improving students' problem solving skills in physics.

Mahasneh (2017) investigated the impact of the e-mind mapping strategy on attitudes of students towards educational psychology course at the Hashemite University. He investigated the impact of this strategy on achievement in this course. 65 students were sampled. The sample was grouped into experimental and a control group. Data got collected through using a survey, pre-test and post-test. Based on the analysis, the e-mind mapping strategy improves students' attitudes towards the targeted course. It also has a positive significant impact on achievment in this course

Mohaidat (2018) investigated the impact of the e-mind mapping strategy on English reading comprehension among ninth grade students in Jordan during the academic year (2016-2017). The sample consists from 30 students who were selected from two sections in a school in Irbid. The researcher administered pre-test and post-test. He found that the e-mind mapping strategy significantly and positively affect the students' English reading comprehension.

Al-Shdaifat et al. (2019) investigated impact of the e-mind mapping strategy on academic achievement in terms of English vocabulary. The sample consists from 25 primary school students who are EFL learners. Pre-test and post-test were employed. Through processing the collected data, the researchers concluded that e-mind mapping strategy expands students' English vocabulary and improves their achievement in terms of English vocabulary. They recommend providing teachers with training about this strategy.

Al-Omari and Al-Dhoon (2020) investigated impact of the e-mind mapping strategy on achievement of $10^{\text {th }}$ grade students in biology course in Jordan. The control group consist from 24 students and the experimental group consists from 50 students. The researcher administered pre-test and post-test. Based on the results, the e-mind mapping strategy positively affects the achievement of $10^{\text {th }}$ grade students in biology course in Jordan.

\section{Methodology}

\subsection{Approach}

In the present study, the quasi-experimental approach was adopted through dividing the sample into an experimental group and a control group. Both groups have a pre-test for measuring their background knowledge. Then, the lecturing strategy was used to teacher the control group and the e-mind mapping strategy was used to teach the experimental group. Through those strategies, unit 5 of the citizenship and civic education curriculum of 9th grade was taught to both groups. Then, the post-test was taken by the members of both groups. 
The quasi-experimental approach is used for conducting studies in several fields, such as: the medical and social fields. It involves a controlled non-randomized trial. It is adopted to explore the effectiveness of an intervention (e.g. teaching method, drug, or etc..). Some quasi-experimental studies don't use pre-test, whereas other quasi-experimental studies use pre-test and post-test. Some quasi-experimental studies use employs adopt time-series research designs (Harris et al., 2006). The researcher also adopted a quantitative approach. This approach was adopted to collect and analyze data quantitatively through employing the relevant statistical methods (Nassaji, 2015)

\subsection{Research Variables}

The variables are listed below

a) Independent variables: Teaching methods (i.e. e-mind mapping strategy and the lecturing method). The lecturing method may be called the conventional method in this research.

b) Dependent variable: The ninth grade students' academic achievement in the citizenship and civic education course.

\subsection{Data Collection Methods}

Two kinds of data were collected:

a)- Primary data: Such data was collected from the pre-achievement test and post- achievement test.

b) Secondary data: Such data was collected from books, studies, and articles, as well as from the theoretical material of unit 5 of the citizenship and civic education curriculum of $9^{\text {th }}$ grade in Jordan. The latter unit is titled (economic concepts). It consists from three lessons. The first lesson is titled (work). The second lesson is titled (investment). The third lesson is titled (rationalization of consumption). During the trial, each lesson of those was taught through one period.

The first lesson identifies the definition of the term (work) and the term (unemployment). It offers information about the social and economic positive impacts of working on one and society. It identifies the factors that negatively affect the number of available job opportunities. It identifies the positive impact of having women working.

The second lesson identifies the meaning of investment and its types. It identifies the goals sought from making investments. It identifies the positive impacts of making investment on one and society. It identifies the factors that attract foreign investors in general. It identifies the factors that encourage investors to invest in Jordan. The third lesson identifies the meaning of the expression (rationalization of consumption) and its positive impacts on one, family and society. It sheds a light on mechanisms for rationalizing the consumption of electricity.

\subsection{Population and Sample}

The population is represented in all the ninth grade students who are enrolled in Jordanian schools. The sample was selected purposively from the population. It consists of 40 ninth grade female students who are enrolled in Princess Sukayna bent Al-Hussain School for girls in Amman, Jordan. They were selected from two (2) sections. Section. The experimental group (section a) include 28 students. The control group (section b) includes 27 students. Table 1 presents the distribution of the sample in accordance with the groups.

Table 1. The distribution of the sample in accordance with the groups.

\begin{tabular}{llll}
\hline Group & Section & Strategy & Number \\
\hline Experimental & $\mathrm{A}$ & $\begin{array}{l}\text { The e-mind mapping } \\
\text { strategy }\end{array}$ & 28 \\
Control & $\mathrm{B}$ & $\begin{array}{l}\text { The traditional strategy } \\
\text { (i.e. the lecturing strategy) }\end{array}$ & 27 \\
Total & $\mathrm{N}=55$ & & \\
\hline
\end{tabular}

\subsection{Statistical Analysis Methods}

To analyze data, SPSS program was used. Descriptive statistical methods were employed. Therefore, the arithmetic means and standard deviations were calculated for achievement on both tests. Inferential statistical methods were used. For instance, ANCOVA analysis and Eta-Squared were carried out.

\subsection{Validity of the Tests}

The initial version of the pre-test and the initial version of the post-test were passed to three experts in educational sciences. Those experts are faculty members in a Jordanian public university. They were asked to assess both tests in 
terms of language, content and relevancy to the study's goal. They were asked to make changes to the tests. They added that both tests are clear, and capable to meet the goal of the study. One of the experts recommended re-drafting two items in the post-test. Another expert recommended deleting an item in the pre-test. Thus, changes were made and the final version of each test was drafted.

\subsection{Reliability of the Tests}

To measure reliability, the researcher passed the pre-test and post-test forms to 26 ninth grade students. Those students aren't members in the actual sample. They studied the targeted unit. The researcher passed the post-test forms again to those students after two weeks. Then, Cronbach's alpha coefficient values were. The value of the pre-test is 0.94 , and the value of the post-test is 0.88 . Thus, both tests are reliable instruments. That is because those values are greater than 0.70 as it's suggested by Salehi \& Farhang (2019).

\subsection{Procedures}

- To collect the required data, the relevant theoretical and empirical literature were reviewed. The citizenship and civic education curriculum of $9^{\text {th }}$ grade in Jordan was reviewed too. The researcher chose the unit to be taught which unit No. 5. This unit is titled (economic concepts)

- A sample consisting of 55 ninth grade students were selected purposively from two sections of Princess Sukayna bent Al-Hussain School for girls. This school is located in Amman, Jordan. Section A represents the experimental group (28 students), whereas section B represents the control group (27 students).

- The researcher developed the initial version of the pre-test and the initial version of the post-test. The pre-test sheds a light on general knowledge. The post-test sheds a light on unit 5 of the curriculum.

- $\quad$ Both tests were passed to experts to asses them. Changes were made and the final version of each test was drafted.

- The reliability of each test was measured through calculating Cronbach alpha coefficient values

- $\quad$ Each test consists from 35 multiple choice items (one score per item). A cover page was attached to each test which includes essential information about the main purpose of the study and the test instructions.

- The pre-test was taken by both groups. The scores on the pre-test were analyzed. Based on such analysis, the researcher found that both groups are equivalent in terms of background knowledge.

- The researcher designed the e-mind maps which cover unit No. 5 in the curriculum. Then, the teacher illustrated unit 5 to the experimental group through the using the e-mind maps. He illustrated it throughout three periods. The teacher also illustrated unit 5 to the control group through the lecturing strategy (i.e. the conventional strategy) throughout three periods.

- The post-test was taken by both groups. Then, the scores on this test were analyzed through using SPSS software.

- Results and recommendations were drafted.

\section{Results and Discussion}

There isn't any statistically significant difference - at the statistical significance level of $\alpha \leq 0.05$ - between the control and experimental group in terms of achievement on the post-test in the citizenship and civic education course.

In order to test the main hypothesis, the researcher calculated the arithmetic means and standard deviation for the scores of both groups on both tests. Such values are shown in table 2.

Table 2. Arithmetic means and standard deviations for the scores of both groups on both tests

\begin{tabular}{llllll}
\hline Group & No. & $\begin{array}{l}\text { Pre-test } \\
\text { Mean }\end{array}$ & $\begin{array}{l}\text { Standard } \\
\text { deviation }\end{array}$ & Mean & $\begin{array}{l}\text { Standard } \\
\text { deviation }\end{array}$ \\
\hline Experimental & 28 & 13.75 & 5.93 & 32.89 & 6.08 \\
Control & 27 & 12.81 & 7.68 & 22.90 & 9.50 \\
Total & 55 & 13.29 & 6.80 & 28.00 & 9.35 \\
\hline
\end{tabular}


Table 3. ANCOVA analysis of the means acquired by the experimental group and the control group

\begin{tabular}{lllllll}
\hline Source & $\begin{array}{c}\text { Type III Sum } \\
\text { of Squares }\end{array}$ & df. & Mean Square & F & Sig. & $\begin{array}{c}\text { Partial Eta } \\
\text { Squared }\end{array}$ \\
\hline Pre-test & 3526.919 & 1 & 3526.919 & 81.391 & 0.000 & \\
Method/Group & 903.695 & 1 & 903.695 & 20.855 & 0.000 & 0.307 \\
Error & 2036.662 & 47 & 43.333 & & & \\
Total & 4718.000 & 54 & & & & \\
\hline Based & & & & & &
\end{tabular}

Based on table 2, the mean of the experimental group on the pre-test is 13.75. The mean of the experimental group on the pre-test is 12.81. Thus, there is a difference between the experimental and the control groups in terms of the mean on the pre-test. To identify whether this difference is significant, ANCOVA analysis was carried out. Based on this analysis, the latter difference isn't significant statistically. To be specific, there isn't difference between both groups in terms of mean on the pre-test. That indicates that both group are equivalent in terms of background knowledge. That means that the Ministry of Education provides much attention to the citizenship and civic education course. It indicates that the teachers of the course exert much effort to expand students' knowledge in this regard. It indicates that the curricula of this course are rich with information.

Based on table 2, the mean of the experimental group on the post-test is 32.89 . The mean of the experimental group on the post-test is 22.90. Thus, there is a difference between the experimental and the control groups in terms of the mean on the post-test. To identify whether this difference is significant, ANCOVA analysis was carried out. Based on this analysis, the latter difference is significant statistically. Thus, there is a difference between the groups in terms of the mean on the post-test. That's because the F value is 20.855 and the significance level is 0.000 .

Table 4. Shows the adjusted means and the standard errors for experimental and control groups on post-achievement test.

\begin{tabular}{lll}
\hline Group & Adjusted mean & Standard errors \\
\hline Experimental group & 32.08 & 1.26 \\
Control group & 23.77 & 1.28 \\
\hline
\end{tabular}

In order to identify the group that the difference is for their favor, the adjusted means and the standard errors. The latter values in table (4). As shown in table 4, the adjusted mean of the experimental group is 32.08 . This value is greater than the adjusted mean of the control group (23.77). Furthermore, the standard error of the experimental group is 1.26 , while that of the control group is 1.28 . Based on these values, a significant difference exists - at the statistical significance level of $\alpha \leq 0.05$ - between both groups in terms of the mean on the post-test for the favor of the experimental group. That means that the e-mind mapping strategy is more effective than the lecturing strategy for improving the achievement of Jordanian $9^{\text {th }}$ grade students in the citizenship and civic education course. The latter result is consistent with the result concluded by Al-Fawri (2009). For instance, the latter researcher found that the mind mapping strategy is effective for improving students' achievement in the social studies course in Oman.

The result in this regard be attributed to the fact that the e-mind mapping strategy improves students' problem solving skills (Zaytoon and Baker, 2016), contemplative thinking skills (Al-Sherbini, 2016), creative thinking skills (Al-Balawi, 2015). Thus, the development of such skills shall contribute to raising achievement and promotes deeper understanding for the material.

The result in this regard be attributed to the fact that the e-mind mapping strategy improves students' students' cognitive functions of the brain and memory performance and facilitate the learning process (Abdulrazeq, 2016). Thus, students' ability to retrieve information while taking exams in this course shall be improved. That shall lead to raising achievement.

The result in this regard be attributed to the fact that this strategy contributes to organizing and sharing information (Hasan, 2013). That shall make it easier for students in this course to acquire information and memorize them in the long-term memory. It shall make students show more concentration. That shall positively affect their achievement in this course. In addition, the result in this regard be attributed to the fact that this strategy motivates students to learn and expand their knowledge (Jones et al., 2012). That shall make them well-prepared for exams. Thus, students shall show better scores on exams.

\section{Conclusion}

The following results were reached: 
a)- There isn't difference between both groups in terms of mean on the pre-test. That indicates that both group are equivalent in terms of background knowledge. That means that the Jordanian government is keen on providing students with much knowledge about their homeland, and national history and heritage. It indicates that the Jordanian government is keen on promoting citizenship values.

b)- There is a significant difference existing - at the statistical significance level of $\alpha \leq 0.05$ - between both groups in terms of the mean on the post-test for the favor of the experimental group. That means that the e-mind mapping strategy is more effective than the lecturing strategy for improving the achievement of Jordanian $9^{\text {th }}$ grade students in the citizenship and civic education course. This result indicates that teachers in (citizenship and civic education course) must carry out e-mind mapping activities to provide to promote citizenship values among students and expand their knowledge about their rights, freedoms and obligations. It indicates that such activities shall promote knowledge about national history, customs and traditions. It indicates that such activities shall promote loyalty and sense of belonging.

c)-The results of this study indicate that developers of (citizenship and civic education) curricula must add e-mind mapping activities to such curricula.

\section{Recommendations}

In this research, the following are recommended:

1)- Developing special software and programs that can facilitate the processes of designing and presenting e-mind maps in courses.

2)- Providing schools with advanced technologies, such as: computers, and data shows. That shall allow teachers to employ technology-based instructional strategies.

3)- Providing the Jordanian teachers with training programs about the technology-based instructional strategies. Such training programs must shed a light on the e-mind mapping strategy

4)- Adding virtual activities to the curricula of special citizenship and civic education courses. That shall promote loyalty and citizenship values among students.

\section{Recommendations for Researchers}

The researcher recommends:

-Conducting a study about the effectiveness of using the e-mind mapping strategy for training teachers in the Queen Rania Teacher Academy in Jordan.

-Conducting a study about the effectiveness of using the e-mind mapping strategy for teaching the ones who suffer from auditory impairments in Jordan.

-Conducting a study about the effectiveness of using the e-mind mapping strategy for teaching English to kindergarten students.

There isn't any study conducted about those subjects. Thus, that shall contribute to filling a gap in the relevant literature.

\section{Acknowledgment}

The researcher would like to thank the management of Al-Balqa Applied University for providing him with support.

\section{References}

Abdulbaset, H. (2016). Digital Mind Maps and their Activities in Education and Learning. The Electronic Educational Journal, Issue (12). Retrieved from: http://emag.mans.edu.eg/index.php?page=news\&task=show\&id=396

Abdulrazeq, Al-Saee'd (2016). The Educational Electronic Mind Maps, The Electronic Educational Journal, Issue (9). Retrieved from: http://emag.mans.edu.eg/index.php?page =news\&task=show\%5C\&id=256

Alazzi, K. (2012). To What Extent the Social Studies Curriculum in Jordan Promote Core- democratic Values: Knowledge, Skills, and Participation, Journal of Emerging Trends in Educational Research and Policy Studies, 3(1), 1-10.

Al-Balawi (2015). The Effectiveness of both Computed Mind Maps Strategy and concepts maps strategy in developing the skills of creative thinking in the curriculum of middle school of social and national studies at the students of 3rd grade, Middle School. Published MA thesis, Taibah University, Saudi Arabia。 
A-Fawri, Ruqaya (2009). The effectiveness of the mind mapping strategy in improving the academic achievement of $9^{\text {th }}$ grade female student in social studies in Sultanate Oman and their attitudes towards it, Unpublished MA thesis, Sultan Qabous University, Sultanate Oman。

Al-Gassem, T. (2020) The Role of Jordanian Universities in Promoting Citizenship Values among Students. Journal of Education and Practice, 11(33), 40-50. https://doi.org/10.7176/JEP/11-33-08

Al-Haroun, Shaima' (2007). A proposed strategy for developing some scientific concepts, and affective and met-memory skills among the special need preparatory stage students who are advanced cognitively, Unpublished PhD dissertation, Ain Shams University, Egypt.

Al-Jarf, R. (2011). Teaching spelling with mind-mapping software. Asian EFL Journal. Professional Teaching Articles-CEBU, 53(3), 4-16.

Al-Khazaleh, Ahmed Mohammed (2018) "The Level of practicing National Values from the point of view of Students who Studied National Education Book at AL ALBYT University in Jordan," Journal of Al-Quds Open University for Educational \& Psychological Research \& Studies, 8(24), Article 7. https://doi.org/10.5281/zenodo.1344947

Al-Mutairi, S. (2016) The effect of using mind mapping software on developing the EFL vocabulary achievement of Saudi sixth grade pupils, published MA thesis, Taibah University, Saudi Arabia.

Al-Omari, A., \& Al-Dhoon, B. (2020). The Impact of E-Mind Mapping Strategy and Learning Styles on the Achievement of the Tenth- Grade Students in Biology. Universal Journal of Educational Research, 8(12), 6429-6438. https://doi.org/10.13189/ujer.2020.081208

Al-Refai', Najib (2006). Academic skills, (6th ed.), Kuwait: Maharat Co. for consultancy and training.

Al-Shdaifat, S., Al-Haq, F., \& Al-Jamal, D. (2019). The Impact of an E-mind Mapping Strategy on Improving Basic Stage Students' English Vocabulary. Jordan Journal of Modern Languages and Literature, 11(3), 385-402.

Al-Sherbini, Amani (2016). The effectiveness of using mind mapping for teaching social studies to middle schools students in the aim of developing their contemplative thinking skills and attitudes towards it, Published MA thesis, Al-Mansoura University, Egypt.

Avgerinou, M., \& Ericson, J. (1997). A review of the concept of visual literacy. British Journal of Educational Technology, Vol. 28, 280-291. https://doi.org/10.1111/1467-8535.00035

Bani Fares, Mahmoud (2013). Effect of using mind-maps strategy on intermediate school students' acquisition of historical concepts and their creative thinking skills in Madinah Munawarah. The Islamic University Journal for educational and psychology studies, Issue (4), 59-94.

Bruce, H. C., \& Neville, P. (1979). Evaluation in education. Oxford: Pengamon Press.

Buzan, T., \& Buzan B. (1993). The mind map book: how to use radiant thinking to maximize your brain's untapped potential [J]. New York, Penguin Group.

Buzan, T., \& Buzan, B. (1996). The mind mapping book: How to use Radiant Thinking to maximize your brain's untapped potential. London: BBC.

Buzan, T. (2006). Mind Maps for Kids: An Introduction. Harper Thorsons, Hammersmith, London.

Farrand, S., Hussain, F., \& Hennessy, E. (2002). The efficacy of the mind map study technique. Journal of Medical Educational, 36(5), 426-431. https://doi.org/10.1046/j.1365-2923.2002.01205.x

Geboers, E., Geijsel, F., Admiraal, W., \& Dam, G. (2013). Review of the effects of citizenship education. Educational Research Review, 9, 158-173. https://doi.org/10.1016/j.edurev.2012.02.001

Harris, A. D., McGregor, J. C., Perencevich, E. N., Furuno, J. P., Zhu, J., Peterson, D. E., \& Finkelstein, J. (2006). The use and interpretation of quasi-experimental studies in medical informatics. Journal of the American Medical Informatics Association: JAMIA, 13(1), 16-23. https://doi.org/10.1197/jamia.M1749

Harris, J., Al-Bataineh, M., \&Al-Bataineh, A. (2016). One to One Technology and its Effect on Student Academic Achievement and Motivation. Contemporary Educational Technology, 7(4). 368-381. https://doi.org/10.30935/cedtech/6182

Hasan, Shaima' (2013a). The effectiveness of electronic mind mapping in developing organizational thinking and decision making skills among intermediate school students, The journal of mathematical education, 16(2), 31-84. 
Hasan, Shaima' (2013b). The effectiveness of electronic and paper-based mind maps in teaching syntax for $6^{\text {th }}$ grade students in the aim of developing their syntax related terms, Knowledge and Reading Journal, 16 (2).

Haynes, J., \& Passy, R. (2013). Education, extremism and terrorism: what should be taught in citizenship education and why. Journal of Education and Teaching, 39(4), 464-466. https://doi.org/10.1080/02607476.2013.825458

Hilal, Mommad Abed Al-Gh'ani (2007). The skills of accelerated learning, speed reading and mind mapping, Egypt, Cairo, Performance Development and Development Center.

Jbeili, Ibrahim (2013). The Impact of Digital Mind Maps on Science Achievement among Sixth Grade Students in Saudi Arabia. Procedia - Social and Behavioral Sciences, Vol. 103, 1078-1087. https://doi.org/10.1016/j.sbspro.2013.10.435

Jonassen, D. (2005). Modeling with technology: Mind tools for conceptual change. Educational Technology \& Society, 10(2), 225- 227.

Jones, Brett D., Ruff, C., Snyder, Jennifer D., Petrich, B., \& Koonce, C. (2012) "The Effects of Mind Mapping Activities on Students' Motivation. International Journal for the Scholarship of Teaching and Learning, 6(1), Article 5. https://doi.org/10.20429/ijsotl.2012.060105

Mahasneh, A. (2017). The Effect of Using Electronic Mind Mapping on Achievement and Attitudes in an Introduction to Educational Psychology Course. The New Educational Review, Vol. 47, 295-304. https://doi.org/10.15804/tner.2017.47.1.23

Margulies, Nancy (2001). Mapping inner space: learning and teaching mind mapping ( $2^{\text {nd }}$. Ed.). Thousand Oaks, CA: Crown Press.

Mohaidat, M. (2018). The Impact of Electronic Mind Maps on Students' Reading Comprehension. English Language Teaching, 11(4). 32-42. https://doi.org/10.5539/elt.v11n4p32

Nassaji, H. (2015). Qualitative and descriptive research: Data type versus data analysis. Language Teaching Research, 19(2), https://doi.org/10.1177/1362168815572747

Salehi, M., \& Farhang, A. (2019). On the adequacy of the experimental approach to construct validation: the case of advertising literacy. Heliyon, 5(5). https://doi.org/10.1016/j.heliyon.2019.e01686

Subheyyin, E., Mawajdeh, B., Talhouni, M., \& Rfou, M. (2017). The Status of National Values in the Books of Social Studies for the Grades of the Upper Primary Stage in Jordan. Journal of Education and Practice, 8(13). 1-7.

The Jordanian Ministry of Education (1997). Education Act No 3 of 1994. Amman, Jordan Ministry of Education Press.

Tsereteli, M. (2014). The impact of a teaching methodology on students' academic achievement. The Proceedings of 8th International Technology, Education and Development Conference, 4998-5001, Valencia, Spain, 10-12/March/ 2014. https://library.iated.org/view/TSERETELI2014IMP

Tucker, J. M., Armstrong, G. R., \& Massad, V. J. (2010). Profiling the mind map user: A descriptive appraisal. Journal of Instructional Pedagogies, 2(4), 1-13.

Waqad, Hadeel (2009). The effectiveness of mind maps on the academic achievement of $11^{\text {th }}$ grade female students in some topic in biology at Makah Al-Mukaramah, Unpublished MA thesis, Um Al-Qura University, Saudi Arabia.

Zaytoon, A'yesh \& Baker, Hadeel (2016). The effect of using computerized mind maps strategy on solving physics problems of the Tenth basic grade female students in the light of their learning styles. Dirasat Journal for educational sciences, 43(3), 1841-1859.

Zhang, Y., Xiao, S., Yang, X., \& Ding, L. (2010). Mind Mapping Based Human Memory Management System. Presented at the International Conference on Computational Intelligence and Software Engineering (CISE), China. https://doi.org/10.1109/CISE.2010.5676752

\section{Copyrights}

Copyright for this article is retained by the author(s), with first publication rights granted to the journal.

This is an open-access article distributed under the terms and conditions of the Creative Commons Attribution license (http://creativecommons.org/licenses/by/4.0/). 